\title{
Religion and Cultural Interaction in the Republic of Buryatia
}

\author{
Darima D. Amogolonova and Marina M. Sodnompilova* \\ Institute for Mongolian, \\ Buddhist and Tibetan Studies SB RAS \\ 6 Sakhyanovoi, Ulan-Ude, 670047, Russia
}

Received 20.01.2016, received in revised form 18.02.2016, accepted 04.03.2016

The paper discusses the processes of interaction between religious groups and institutions in post soviet Buryatia in the context of a religious revival in Russia. The authors argue that swift return of religiosity from periphery to the center of social practices results rather from the ideological reasons then radical worldview change. Religious belonging as the principal marker of ethnocultural identity promotes growing interest in Buddhism and Shamanism among Buryats, while ethnic Russians feel their deep ties with Russian Orthodoxy. Simultaneously, common regional cultural text that has been created for centuries still supports a kind of syncretic belief that is maintained by indistinct religious representations. In its turn, this situation strengthens interethnic consent and tolerance.

Keywords: Buryatia, modern Buddhism, Shamanism, Orthodoxy, religious belief, religiosity, ethnic identity, religious revival.

The research has been carried out at the support of the Russian Science Foundation, Project 1418-00444 "Buddhism in social, political and cultural processes of Russia, Inner and East Asia: transformations and prospects".

DOI: 10.17516/1997-1370-2016-9-4-960-970.

Research area: culture studies.

\section{Introduction}

The return of religion in socio-cultural practices of post soviet space gave birth to numerous questions concerning politics, ideology, social and individual consciousness and values. For scholars, one of the principal problems is ascertainment what is religious revival and whether present-day religiosity (nearly overall) has something to do with religious belief. Does the modern rationalized mind really coexist with irrational belief in supernatural? Can we assume that throughout the history of the Soviet Union, the soviet citizens were latently believers and consequently after collapse of the atheistic ideology their religious belief simply took manifest forms? Or, on the contrary, transition from the official ideology of atheism to desecularization practices is nothing then a new ideological campaign?

We realize that it is hardly possible to answer these questions irrefragably. We simply study the religious revival in Buryatia that is a

(C) Siberian Federal University. All rights reserved

* Corresponding author E-mail address: amog@inbox.ru, sodnompilova@yandex.ru 
territory of cultural interaction. It is interesting to analyze both religious practices and their functional context taking into consideration the role of religion in ethno-social identification. The problem is topical from various points because religion has become a substantial element in social processes from politics up to interpersonal relations.

\section{Materials and Methods}

In the paper, we employ field materials of our own including questioning, qualitative interviewing, observation and participation in religious rituals and worshipping. In addition, we used mass media materials including Internet and writings of the religious leaders.

The research methods are based on the latest theoretical developments in religious studies, sociology of religion, and social anthropology. The basic watershed is conditioned by secularization theory as the characteristic of the modernized communities. E. Gellner expressed the most common idea of secularization as following: in the conditions of scientific-industrial society, religious belief and rituals decline because religious doctrines are in conflict with scientific doctrines that are the base of modern technologies and economy. For this reason, religious faith reduces while the prestige of scientific worldview increases (Gellner, 1992: 4). The opposite position declares that at present the positions of religion in various areas of public life are getting stronger, in particular, when religious belonging acts as an important marker of social identification and differentiation. Thus religious and secular, sacred and worldly coexist even in the case of rationalized public and individual consciousness. This quality of present-day spirituality American sociologist Douglas Massey explains proceeding from psychology: 'The point is that we are not only rational. What makes us human is the addition of a rational mind to a preexisting emotional base.
Sociology's focus should be on the interplay between rationality and emotionality, not on theorizing the former while ignoring the latter or posing one as the opposite of the other. Attempting to understand human behavior as the outcome of rational cognition alone is not only incorrect - it leads to fundamental misunderstandings of the human condition' (Massey, 2002: 2).

In addition, religious values in various respects mark refusal from modernization that brought to globalization, which paradoxically includes destructive context of confrontation and division along religious borders. This inevitably results in politicization of religion or more properly religious belonging. The most pessimistic view on a problem was offered by Samuel Huntington who considered the modern international and national conflicts from the point of clash of civilizations some of them are called by religions: Islamic, Hindu, and Slavic-Orthodox. He argues: '...the fundamental source of conflict in this new world will not be primarily ideological or primarily economic. The great divisions among humankind and the dominating source of conflict will be cultural. Nation states will remain the most powerful actors in world affairs, but the principal conflicts of global politics will occur between nations and groups of different civilizations. The clash of civilizations will dominate global politics. The fault lines between civilizations will be the battle lines of the future. Conflict between civilizations will be the latest phase in the evolution of conflict in the modern world'(Huntington, 1993: 22). Simultaneously, scientific discourse returns back to pre-modernist interpretation of religion, according which there exists a phenomenon of religion sui generis or 'pure religion' that is peaceful and tolerant while terrorism and intolerance are 'abuses' (Brill Dictionary, 2006: VII-VIII).

Finally, interaction of cultures gives birth to interpenetration of religious representations that 
is interpreted in science as religious syncretism and 'patchwork' religion that is, according to Hermann Denz, 'religion + a little something else'. Explaining this 'something', he says that 'Grand churches and theology do not approve of daemons, magic and everything that is related to these things to a great extent. This holds for the present as well as for the individual epochs in church history. With popular religion however which has always had a tendency to combine different teachings and cults and is indifferent towards dogmas - they have always enjoyed great popularity' (Denz, 2009: 184). By the way, free interpretation of dogmas is peculiar not only to the modernized consciousness: in no less degree, it testifies to personal religiousness that is a widely spread phenomenon all over the world and in particular in the former atheistic countries.

Since late 1980 -es, the socialist societies have faced returning religion and enormous growth in number of churches and clergy. This was urged to fill in the ideological vacuum and thus appeared to be the element of state program. One can see that post-soviet desecularization appeared a political campaign that similarly to previous creed had to unite and consolidate the nation. Reaccentuation in social functions of religion is in particular evident in multicultural communities in which ethnic and cultural identification still occupies prominent position in public discourse. In our case, religion has become a strongest element of we-image in the Republic of Buryatia that has since old times been a territory of cultural interaction between Russians and Buryats.

\section{Results}

Throughout the post soviet period, the changes in the ethnicization of social consciousness manifested, perhaps above all, in the religious sphere. Qualitative characteristics of the relationship between the churches and the community show that in modern Buryatia a certain imbalance has come into being in the cultural image of the geographical space. The position of Orthodoxy, which is the main religion of Russia and nominally professed by the majority of the republic's population, in the social significance, is inferior to Buddhist-Shamanic complex that is the main cultural characteristics of the region. The difference in social status is determined by the fact that Buryatia is the Buddhist center of Russia: here focuses the institutionalized Buddhism, which is currently undergoing a reformation. To overcome the imbalance, in 2009 the Ulan-Ude and Buryat diocese was founded that grew to the Metropolitanate in 2015 (headed by the former Archbishop and now Metropolitan Savvatiy). This event contributed to the revitalization of the Orthodox Church as the status of Metropolitanate gives wider opportunities in conducting direct dialogue with the authorities, receiving state financial and organizational support, publishing religious literature and periodicals, opening Sunday schools, etc. The regional Orthodox ideology has been strengthened mainly thanks to Savvatiy's efforts. The higher status of Orthodoxy in the republic, he argues, will promote rapprochement between highest clergy (bishops and archbishops) and people (Danilov, 2014). Approving the tradition of inter-ethnic stability in the republic, Savvatiy simultaneously speaks about "limited tolerance" that must be introduced into the consciousness of the Orthodox. Thus, religious syncretism will be overcome and the positions of the Orthodox identity will be restored: 'People living in Buryatia are friendly and show understanding and goodwill to each other, but therein the danger lies. From time immemorial, people live here together and accept people of other faiths. They are ready to listen and learn from others. <..> It is necessary to build a relationship so that a person would have his inner core and realize who he is, what religion 
he confesses, and what are his roots' (Batorova 2012).

The head of the Buryat Buddhists Hambo Lama Damba Ayusheev is of different opinion in the question of interfaith relations: despite the fact that he disapproves of Buddhist religious communities outside the Buddhist Traditional Sangha of Russia, he does not build boundaries between religions identifying as a Buddhist any person who believes for $60 \%$ in the supreme forces (Mahachkeev, 2010: 144).

However, for the Hambo Lama the fact of separate cultural-spatial characteristics of religion is evident. Thus, the Orthodox Christianity and Buddhist-Shamanic complex delineate the boundaries of Russian and Buryat cultural ethnosphere. Accordingly, such a reading of religion inevitably transforms into the idea of 'own' and 'others' space. In such a situation, both the officially recognized religious institutions and the state must observe the principle of religious equality. ${ }^{1}$ At present, on the all-Russia scale, the Russian Orthodoxy that is formally confessed by the majority of population occupies a special place in Russia. ${ }^{2}$ So, in the territories of clustered dwelling of non-Christians, the status of other officially recognized religions is meant as at least equal within these territories.

In Buryatia, a special law passed by the People's Khural (parliament) of the Republic in 1997 regulates the religious sphere (Religious organizations, 2011: 187-1911). According the law, the religions confessed in Buryatia are the following: the Buddhist Traditional Sangha of Russia, Old Belief, Christianity, and Shamanism (Religious organizations, 2011: 187). This article of the law is remarkable for its regional specificity. The Buddhist religion is not mentioned but the first place in the listed 'historically developed confessions' is given to the Buddhist Traditional Sangha of Russia (BTSR), which, however, is not a religion but a religious institution that unites all those who recognize their affiliation with the organization. Consequently, the law protects the position of BTSR not all Buddhist organizations of the republic. Conversely, the law reads Christianity in general, whereas of course on the territory of Buryatia, key positions in spreading and historical significance belong to the Russian Orthodoxy. Actually, the logics demand that if instead of Buddhism the law reads the BTSR, then there should be not Christianity but the Russian Orthodox Church.

As for Buddhism, the present-day legislation in many respects follows both the Russian imperial and soviet tradition. Let us recall that the Russian state recognized Buddhism as one of religions of the subjects of the Russian tsars; simultaneously, this implied the all-round control over it. Due to cultural and historical reasons and geographical remoteness, the Buddhist church in Kalmykia and Buryatia were not linked and this was certainly aggravated by the Russian government policy, according to which the bureaucratization of religious leaders of Buryats and Kalmyks was built in similar ways, but separately. The Regulations on the Management of the Kalmyk people came into being in 1847, according to which all religious power was concentrated in the hands of the supreme Lama of the Kalmyk people appointed by the Senate. The Ministry of State Property undertook the supervision. The Regulations on Lamaist clergy in Eastern Siberia were issued in 1853, which provided the department of foreign religions at the ministry of home affairs as a supervising body. In the soviet time, the regulative functions were in the hands of the Central Spiritual Board of Buddhists of the USSR (CSBB) located in the Ivolga Datsan in Buryatia and headed by the Buryat Hambo Lama. Nominally, the organization was considered as a supreme body of all Buddhists in the USSR, however in practice it regulated mainly the religious life of Buryats. 
The uncertainty in the status of the organization has been overcome by the Hambo Lama Damba Ayushev who, firstly, changed the name of the organization in the Buddhist Traditional Sangha of Russia (BTSR) in 1997 and, secondly, legalized real-life situation: the BTSR does not include the Buddhist communities of Kalmykia and Tuva. Still, the Buddhist Traditional Sangha of Russia has become the most authoritative Buddhist organization in Russia and the Hambo Lama has become the Buddhist leader of all-Russian scale.

Unlike the imperial period, the status of the present-day Hambo Lama is much stronger and more independent. According to the Charter, the Hambo Lama 'acts on behalf of the Sangha of Russia without power of attorney, represents it in all institutions, enterprises and organizations, opens settlement and other accounts in banks, issues powers of attorney, manages the funds in accordance with the approved budget' (History of Buddhism, 2011: 335).

Strengthening position of Buddhism within BTSR promotes training clergy to meet the needs of old and new datsans. By now, in the ethnic Buryatia there are two Buddhist higher educational institutions: the Buddhist Institute Dashi Choynhorlin at the Ivolginsky datsan and the Buddhist Academy at the Aga datsan in the Trans-Baikal region. In addition, the tradition of training Buddhist lamas in Mongolia and India continues, so now many lamas in Buryatia have highly qualified theological training along with education in the field of Indo-Tibetan medicine and astrology.

Public opinion polls conducted in Buryatia in recent years show an overwhelming level of religiosity among Buryats with the reducing number of non-believers falling to almost prerevolutionary (before 1917) ${ }^{3}$ levels: for example, among the urban Buryat women the total number of convinced believers and undecided tending towards the faith was $96.4 \%$ (among Buryat men - 79.6\%) (Budaeva et al., 2010: 48), with the majority of respondents identifying themselves as Buddhists.

Though the number of people identifying themselves with the Buddhist religion is in Buryatia only about one-third of the population (the majority of the population identify themselves as Buddhists only in Tuva, in Kalmykia about half) (Yakunin et al., 2009: 32), yet modern Buryatia shows a certain imbalance in the spiritual image of the humanitarian-geographical space. The positions of the Orthodoxy nominally confessed by the majority of the republic's population are inferior in the social significance to the Buddhist-Shamanic complex, which is the main cultural characteristic of the region. Buryatia is considered the Buddhist center of Russia (largely due to the activity of Hambo Lama Damba Ayusheev) and this fact defines the difference in social status between Buddhism and Orthodoxy. Even more important is Hambo Lama D.-D. Itigelov's Precious and Inexhaustible Body that is preserved in the Ivolga datsan.

Meanwhile, the revival of the Orthodoxy in Buryatia is no less impressive. On the eve of the Revolution of 1917, in Buryatia there were about two hundred Orthodox churches and two monasteries. By the end of 1980-es, in the whole republic the only functioning Orthodox church was the Ascension church in Ulan-Ude. In the late 1980-es the Trinity Church in Ulan-Ude was restored and began functioning, and during the 1990s, the St. Hodigitria Cathedral was restored and returned to the diocese in 2000. In the course of post soviet period, new parishes were opened in all districts of the republic. The Orthodox priests are tirelessly calling the actual and potential parishioners to remember the faith that is inseparable from the ethno-cultural, historical, and political memory of Russians (similar to whole Russia, the number of regular Orthodox parishioners in Buryatia is small). The importance 
of Orthodoxy for the strengthening of Russian ethnic identity is emphasized in the publications of Christian leaders of Buryatia. For example, the former rector of St. Hodigitria Cathedral Eugene Startsev wrote that 'the Russians are now returning back to their roots and will gain strength for the revival only in the Orthodox faith of their pious ancestors' (Startsev, 2001: 4). The same author sees Orthodoxy as a formulated national idea that unite Russians for achieving certain goals, which are not clearly outlined but have a distinct ethnicist character 'deeper we grasp our heritage, more we are aware that the history and culture of ours is permeated with the Orthodoxy. The Orthodox understanding of the world and man in it, place and tasks of the native country in the world have always been our national ideology $<\ldots>$. Having united the tribes into a nation, The Orthodoxy inspired its patriotism, rose above the sinful earth, and indicated the great goal to everyone. Consequently, the outlook of the nation must once again become consistently Orthodox in order the Russians could stand and remain themselves' (Startsev, 2005: 6).

No doubt, regarding spiritual and cultural space, the public mind of the Republic marks in the first place traditional religions in spite of the activity of new (non-traditional) churches. At the same time the ethnic or ethno-cultural is in many cases inferior to the humanitarian-geographical understanding of own space, so religious syncretism coined for centuries continues in the present-day rationalized attitude. The Soviet period contributed to leveling cultural differences in different areas when Buryats were largely urbanized and europeanized by means of cultural russification. Similar to most other regions of the cross-cultural interaction in Russia, Buryatia faces the dominance of Russian culture, especially in urban areas. Religion is an exception: the dominant regional cultural text is determined by the traditions of Buddhism and shamanism, and the majority of population without ethnocultural distinction recognizes this in more or less degree. Sacralization of the space through the enrichment of the concept Buryatia is our native land plays a prominent role in this process by means of the ideology of desecularization when religious worldview is purposefully introduced into the secular social consciousness.

Being the part of the vast Buddhist space Buryatia possesses important sacred signs widespread in Central Asia that are the symbols of the Buddhist culture. These signs include Buddhist monasteries-datsans, praying housesdugans, stupas, statues of deities and other material symbols that mark the spiritual and cultural space. ${ }^{4}$ Significance of Buddhist cultural symbols is especially increasing in the background of Buddhist renovation that is actively developing in Buryatia and in neighboring Mongolia. Sacralization of space takes an important place in the activities of Buddhist church. On the territory of the Republic of Buryatia at the initiative of Buddhist institutions that undergone modernization, Buryats and non-Buryats are involved into the process of Buddhist revival through restoration or reconstruction of the Buddhist shrines, temples, and reproduction and translation of rituals. It is worth noting that the Buddhist revival got momentum in 2002 when a phenomenon of Hambo Lama Dashi-Dorzho Itigelov's Precious and Inexhaustible Body became a miracle recognized both in Russia and abroad. The status of Buryatia as a place where religious miracles really happen grew to the spiritual center of Russia.

The role of the Buddhist Church in the sacralization of space is the most evident. Simultaneously, the symbols of pre-shamanic and shamanic beliefs are still topical; numerous shamanic organizations and independent shamans try their best to popularize shamanism as an indigenous Buryat religion. Many shamans 
who went through a special dedication ritual and received $a$ gift from the ancestors enjoy big authority among people regardless their ethnic identification.

A special attitude to the space causes steadiness of religious syncretism even if the rational choice calls for the ancestors' belief (say, in the case of Christians). The multifunctional signs (points of reference) reflecting the archetypes of human minding included both natural and manmade objects. These created the sacral map of the space mastered by the Mongols. The cult facilities have validity for the multiethnic population in whole. These cults are obo and barisa. ${ }^{5}$ In the Buryat and Mongol tradition, passing by these cult objects it is impossible not to stop for offering. People believe that otherwise they will invite disaster. With mobility that has become a characteristic feature of modern society, today the religious cult objects that are associated with the road are extremely important for any person living in the republic whatever is his/her cultural and ethnic belonging. Ethnic Russian population of the republic also strictly adheres to the traditional rules to be observed in the way. Passing by these sacred places, people throw coins and candies, and splash milk (tea with milk) and alcohol. At the same time, motives for such behavior are different: some of our informants experienced negative consequences if ignored the places of worship while others believe that living in the Buryat land that is sacred and protected by spirits one must respect the traditions of the Buryat people for personal and collective wellbeing.

Thus, Buddhism and shamanism today are equally taking an active part in the construction of the sacred (extraordinary, wonderful) space continuum all over ethnic Buryatia; moreover, neighboring Mongolia and China are importing a number of 'Buryat' ideas. In the space of ethnic Buryatia, one can see a phenomenon of secondary sacralization of space, which is an integral part of the revival of traditional culture. Religion as a basic element of culture is now changing due to the change in the outlook of the population, and vise verso - public minding is changing under the influence of present-day religious policy and ideology.

Ideas about sacred space and its elements, about relationship between the sacred and profane, and about a person and human nature are realized in a complex of customs, prohibitions, signs, and special rites aimed at the positive interaction with the forces that govern life, health, and wellbeing. In Russia in general and in Buryatia in particular, the number of people increases who are convinced that their health, happiness and success in the labor market may be exposed to negative energy of others, in everyday terms this is called evil eye. There is no telling that such views are characteristic for people with low levels of education because educated people often hold the same beliefs giving them a rational explanation. This perception and understanding of the realities of life contributes to the reconstruction and expansion of religious practices and magic tricks aimed at preventing and getting rid of the consequences of irrational negative influences. A significant part of protective religious practices permeates the everyday life and relates to the quite common subjects like clothing and food.

Against the background of negative processes that characterize the current state of healthcare and unavailability for the majority of population the commercial medicine, as well as other reasons, such as late diagnosis of hard and intractable diseases, the popularity of so-called non-traditional medicine is growing (as a matter of fact, this is folk medicine or ethnoscience with its remedies and treatments that should be named traditional medicine ). In the field that is now considered as illegal ${ }^{6}$, shamans, bonesetters, and Buddhist monks possessing knowledge of Tibetan medicine offer medical services. 
For example, one of the most popular treatments is the method of applying, when a sick person is enveloped into the hide of just killed animal so that topographically the animal's inner organs were applied on the sick organs: liver to liver, kidneys to kidneys, etc. This method is more relevant to the field of magic medicine but probably has a certain rational content. This ancient nomadic method of treatment proved to be effective in the treatment of severe forms of certain diseases like pneumonia, the bite of poisonous snakes, gynecological diseases and some other. At present, this method is used in even treating various types of cancer.

Buzaartaha (desecration) is named among the common causes of diseases. A contact with unclean people, animals, objects, for example food or visiting an unclean place can contaminate. All these ideas are still topical. Moreover, the list of unclean people and places is expanding. In the modern interpretations of traditional concepts of unclean places, there are hospitals because they accumulate human misery and disease; accordingly, people whose profession is connected with this - the doctors - are also impure. Various purification rites practiced in the shamanic and Buddhist tradition can remedy the situation. The views reactulized about diseases caused by lack of respect and neglect on the side of people to the gods and spirits (especially in the case of incurable diseases that are often called karmic). In such cases, propitiatory and thanksgiving rites addressed to various deities and spirits have become popular.

Both in the Buddhist and shamanistic practices, the rites of invocation of the soul and redemption of the soul are used as a method of healing magic. The main objective of such rituals is to propitiate or to deceive the evil forces by means of conditional offering instead of a living person. It is noteworthy that such healing is fully driven by desecularization processes and covers in Buryatia a significant share of the multiethnic population.

A positive and more socially significant layer of modern culture that is largely related to the religious and cultural traditions are folk festivals, resuscitated during the surge of ethnocultural revival and at present widely supported by the regional authorities. One of the reasons why the power elites pay attention to traditional culture and promote its reproduction and modernization is the desire to develop Russian and international tourism in the context of worldwide growing interest to ethnic cultures. Against the backdrop of the disappearance of the soviet festivals and coming to life new ones that are unpopular among the population, people approve and support those festivals that go back to the folk and religious traditions. Such festivals Maslenitsa (Shrovetide), Easter and Sagaalgan (White Moon Celebration, the principal Buddhist holiday) are not inherent to specific ethnic groups: they have really become cultural events for the whole population of multiethnic Buryatia. The Fairy Sagaalgan has become one of the most successful commercial projects having become the project of all-Russian and even international scale. Winters fairy-tale characters from Russia and abroad participate in the wide project every year and their number is increasing.

The growing number of mixed marriages contributes to blurring ethnic boundaries. In any case, according to sociological pools, together with ethnic Russians identifying themselves as the Orthodox, 32.17percent of Buryats celebrate Christmas and Easter while 51.74 percent of Russians celebrate Sagaalgan and 28.57 percent enthusiastically support the Buryat sport festival Surkharban that goes back to the traditional sport competition Eryn Gurban naadan (Three games of men) (Randalov et al., 2004: 55). The increasing mobility of the population, related to travels in Russia and abroad, promotes widening 
ideas about others' and incorporating into the world cultural context. Multicultural traditions of Buryatia thus are understood as own and this process is ever widening and strengthening.

The religious component of culture nowadays appears only in a latent form and is still in the periphery of social practices. Filling great respect to religion and religious institutions, our contemporaries still draw a definite line between worldliness and the area of spiritual and religious practices. Moreover, the vast majority of people who regularly or occasionally participate in religious rites proceed from pragmatic reasons. This results in weak knowledge about religious holidays and rituals combined with nearly complete ignorance in the field of dogmatic foundations of religion. Meanwhile, religious education is able to withstand the onslaught of politicized religious fundamentalism related to the fanatical belief in the rightness of the own community instead of learning culture, including religion.

\section{Conclusion}

The modern religious revival in Russia is characterized by strengthening institutionalized religious organizations ratherthanrapprochement between the population and religious cultural and educational complex. Moreover, religious leaders aim primarily at getting help and a variety of benefits from the state. The split of the population by confessional borders is a condition of maintaining a stable social base. More pronounced is the confessional division more profound is the social base of religion. In this sense, banal religiosity ${ }^{7}$ is more obedient and can be easier manipulated then religious belief.

Civil society in Russia and most other former soviet countries remains no more than a declaration. Ethnic and racial differentiation continues to play an almost decisive role in braking all-national state ideology, and many prejudices against the others are forming a new albeit having deep historical roots mythology thus reinforcing mutual mistrust and intolerance. Ethnicized and politicized religious identity becomes the most affordable tool in manipulating public opinion and making the question of the dialogue of cultures nearly insoluble.

Thus, religion and religious belief are interconnected but still separate phenomena. For the specific conditions of the post soviet religious revival, rapprochement between them depends on the successful process of strengthening confidence in the state and the church as the most important social institution. Even if the recovery ideological functions of religion is a highly controversial issue, the secondary functions of religion - identification, regulatory, adaptation, educational and training - are effective tools to maintain stability in the society.

\footnotetext{
This is especially important from the point of Buryat historical memory. In the times of the Russian Empire, only Orthodoxy was the state religion. Forcible baptism of Buryats was not rare and the Buddhism was exposed to discrimination (for details see for example: Amogolonova, 2015b).

2 This is recognized in the official documents, for example in the Federal Law on Freedom of Conscience and Religious Associations (see discussion in Amogolonova 2015a: 227).

3 In 1900, the number of atheists in Russia amounted to $0.2 \%$ (which was similar to world standards) (Lane, Ersson, 2005: $161)$.

4 These include a variety of miraculous manifestations of the divine faces and figures on the rocks. In Buryatia, a famous cult place is the stone in Kurumkansky district, on which the image of the deity self-displayed, in which the Buddhist monks recognized the Goddess Yanzhima. The similar image of the Buddha is in the Murochinsky datsan in the Kyakhta district of Buryatia. The image of the deity opens not to everybody: according to the explanations of the Buddhist clergy, only a sinless person can see the face of God.

5 Obo or barisa are the places for worshipping masters of locality. Traditionally, these are the hips of stones or trees decorated with ribbons and tags. Obo are usually erected by the roads, on mountain passes and at hilltops, at lakes, springs, and on the riverbanks. The derivative notion barisan means the ritual of offering to the spirits.
} 
6 According to the draft law of the Russian Federation, beginning from 2014 to carry out such activities, the healer must have a special license, which at present in Buryatia neither shamans nor Tibetan monks-medical men or bonesetters possess. The law has no effect on sufferers who continue to turn to the healers.

7 Under banal religiosity, we understand lack of correlation between religious ethics and secular practices, occasional church attendance, pure knowledge about dogmatism and content of rituals, and simplistic and pragmatic relation to religion.

\section{References}

Amogolonova, D.D. (2015a). Buddizm v Buryatii: rossiiskoe gosudarstvo i konfessional'naya konkurenciya (Buddhism in Buryatia: Russian state and confessional competition). Strany i narody Vostoka (Countries and peoples of the East), (XXXVI). Pp. 5-41.

Amogolonova, D. (2015b). A Symbolic Person of Buddhist Revival in Buryatia. 'Our Hambo' Damba Ayusheev, In Inner Asia, 2015b, 17 (2), 225-242.

Batorova, D. (2012), 'Nuzhna ne pogolovnaya tolerantnost', - zayavil episkop Savvatii na vstreche so Vsevolodom Chaplinym ('We do not need total tolerance', - said the bishop Savvaty at the meeting with Vsevolod Chaplin). Buryad Ynen, available at: http://burunen.ru/articles/detail.php (accessed 7 November 2012).

The Brill Dictionary of Religion (2006). Edited by K.von Stuckrad (Leiden-Boston: Brill), $2100 \mathrm{p}$.

Budaeva, D.Ts., Merdygeev Z.R., Hanturgaeva N.Ts., Itigilova L.M. (2010). Voprosy sohraneniya $i$ razvitiya tolerantnosti, problemy grazhdanskoi aktivnosti naseleniya Respubliki Buryatiya (Preservation and development of tolerance, the problem of civil activity in the Republic of Buryatia). Ulan-Ude: Buryatskii Gos. Univ. 140 p.

Danilov, O. (2014). Arhiepiskop Savvatii o cerkvi, o vere i moskovskoi strel'be (Archbishop Savvaty on the Church, faith and Moscow shooting). Respublika Buryatiya (Republic of Buryatia) Available at: http:/gazetarb.ru/news/section-society/detail-177083/ (accessed 17 February 2014).

Denz, H. (2009). Religion, Popular Piety, Patchwork Religion. Church and Religion in Contemporary Europe. Results from Empirical and Comparative Research. Wiesbaden: VS Verlag, 183-202.

Gellner, E. (1992). Postmodernism, reason and religion (London \& NY: Routledge, 1992), 108 p.

Istoriya buddizma $v$ SSSR i Rossiiskoi Federacii v 1985-1990gg. (2011). (History of Buddhism in the USSR and Russian Federation in 1985-1999. Edited by N.G. Ochirova. Elista: Min. obraz., kultury I nauki Resp. Kalmykii, 392 p.

Huntington, S. (1993). The Clash of Civilizations?, In Foreign Affairs, Summer, 22-49.

Lane, J.-E., Ersson, S. (2005). Culture and Politics. A Comparative Approach, Burlington, Ashgate Publishing Company, $370 \mathrm{p}$.

Mahachkeev, A.V. (2010). The Portrait of the Hierarch. Ulan-Ude: izd-vo NovaPrint, 204 p.

Massey, D. (2002). A Brief History of Human Society: The Origin and Role of Emotion in Social Life, In American Sociological Review, 2002, 67, 1-29.

Religioznye organizacii Respubliki Buryatiya: slovar'-spravochnik(2011)(Religious Organizations of the Republic of Buryatia: a reference book). Edited by S.V. Vasilyeva, Ulan-Ude: Buryatskii Gos. Univ. 211 p.

Randalov, Yu.B., Prokop'ev, V.B., Matveeva, E.V., Tatarova, S.P., Zhalsanova, V.G., Moloshik, M.V. (2004). Kul'turnye processy $v$ Respublike Buryatiya: ocenki $v$ glazah naseleniya (opyt 
sociologicheskogo izucheniya) (Cultural processes in the Republic of Buryatia: the opinions of the population (an attempt of sociological study). Ulan-Ude: Burytskii Nauchn. Tsentr, 298 p.

Startsev, E. (2001). Slovo redaktora (Editorial). Troickoe slovo Zabaikal'ya, The Trinity word of Transbaikalia, 2001 (1), 3-5.

Startsev, E. (2005). Krepkaya osnova (Strong base). Troickoe slovo Zabaikal'ya, The Trinity word of Transbaikalia. 2005 (4), 3-6.

Yakunin, V.I., Sulakshin, S.S., Simonov, V.V., Bagdasarian, V.E., Vilisov, M.V. (2009). Social'noe partnerstvo gosudarstva i religioznyh organizacii (Social partnership of the state and religious organizations). Moscow: Nauchny exspert, 232 p.

\title{
Религиозно-культурное взаимодействие в Республике Бурятия
}

\author{
Д.Д. Амоголонова, М.М. Содномпилова \\ Институт монголоведения \\ буддологии и тибетологии СО РАН \\ Россия, 670047, Улан-Удэ, ул. Сахьяновой, 6
}

\begin{abstract}
В статье исследуются проиессы взаимоотношений между религиозными сообществами и институтами в постсоветской Бурятии в контексте религиозного возрождения в России. Авторы доказывают, что стремительное возвращение религии с периферии 6 иентр соииальных практик происходит по идеологическим причинам, а не вследствие изменения мировоззренческих установок. Религиозная принадлежность как важный маркер этнокультурной идентичности способствует росту интереса к буддизму и шаманизму среди бурят, а этнические русские ощущают глубокую связь с русским православием. Вместе с тем для полиэтничного населения республики характерен религиозный синкретизм, складывавшийся на протяжении веков и сохраняющийся ныне во многом благодаря поверхностному знакомству с религиозной догматикой. В этих условиях религиозность не становится основанием для межкультурного противостояния и нетерпимости.
\end{abstract}

Ключевые слова: Бурятия, современный буддизм, шаманизм, православие, религиозная вера, религиозность, этническая идентичность, религиозное возрождение.

Исследование выполнено при поддержке Российского научного фонда. Проект 14-18-00444 «Буддизм в сочиально-политических и культурных проиессах России, Внутренней и Восточной Азии: трансформации и перспективыl».

Научная специальность: 24.00.00 - культурология. 